\title{
URETERAL TRIPLICATION ACCIDENTALLY FOUND DURING CERVICAL CARCINOMA OPERATION
}

\author{
Dražan Butorac ${ }^{1}$, Ivka Djaković ${ }^{1}$,Jasminka Malčić ${ }^{2}$ and Ljubomir Jokanović ${ }^{1}$ \\ ${ }^{1}$ Department of Gynecology and Obstetrics, Sestre milosrdnice University Hospital Centre, Zagreb, Croatia; \\ ${ }^{2}$ Department of Diagnostic and Interventional Radiology, Sestre milosrdnice University Hospital Centre, \\ Zagreb, Croatia
}

\begin{abstract}
SUMMARY - Ureteral triplication is a very rare anomaly found in the upper urinary tract. This condition can be connected with a higher incidence of congenital anomalies and predisposition for urinary infections. Operative procedure is considered in cases where symptoms reduce the patient's quality of life. The type of surgical treatment depends on symptom manifestation. The risk of renal failure is usually a deciding factor, which can be found in conditions such as vesicoureteral reflux, obstruction, ureteral ectopy and recurrent infections. Simultaneous treatment of upper and lower urinary tract can be performed. We report a case of a 38-year-old female patient diagnosed with cervical carcinoma, where ureteral triplication was detected incidentally during a radical operative procedure.
\end{abstract}

Key words: Ureteral triplication; Cervical carcinoma; Congenital anomalies

\section{Introduction}

Ureteral triplication is a very rare anomaly found in the upper urinary tract. Its clinical value is not high. This condition can be linked to a higher incidence of congenital anomalies and predisposition for urinary infections ${ }^{1,2}$. Since the occurrence of the anomaly is extremely low, available literature is scarce. In Smith's classification, there are four subtypes of ureteral triplication, as follows ${ }^{3,4}$ :

type 1: complete ureteral triplication ( 3 ureters and 3 draining orifices to the bladder);

type 2: incomplete triple ureter with bifurcation of one of them ( 3 ureters and 2 draining orifices to the bladder);

type 3: trifid ureter (3 ureters with only 1 draining orifice to the bladder); and

type 4: double ureter with an inverse Y-bifurcation of one ureter $(2$ ureters and 3 draining orifices to the

Correspondence to: Ivka Djakovic, $M D$, Department of Gynecology and Obstetrics, Sestre milosrdnice University Hospital Centre, Vinogradska c. 29, HR-10000 Zagreb, Croatia

E-mail: ivkadj@yahoo.com

Received March 27, 2017, accepted September 27, 2017 bladder). These types are found in 35\%, 21\%, 31\% and $9 \%$ of cases, respectively. The anomaly is more often located on the left side. When diagnosing the condition, other urologic, as well as non-urologic anomalies should be considered and sought for ${ }^{4-8}$.

We present a case of a 38-year-old female patient with cervical carcinoma having undergone radical surgery, when ureteral triplication was detected incidentally. She had type 2 triplication, with no clinical symptoms occurring prior to operative procedure.

\section{Case Report}

A 38-year-old female patient presented with an abnormal cytologic finding, followed by colposcopy examination. In addition, biopsy of the suspicious area on the cervix with curettage was taken for further analysis. She had no prior history of medical diseases. She was a smoker and vegetarian. She gave birth twice.

Histopathologic analysis of the biopsy showed adenocarcinoma of the cervix, while curettage was nonspecific. Considering the result of the biopsy, cervical amputation was indicated. Biopsy result was: adenocarcinoma cervicis uteri T1bNxMx G2 (according to 


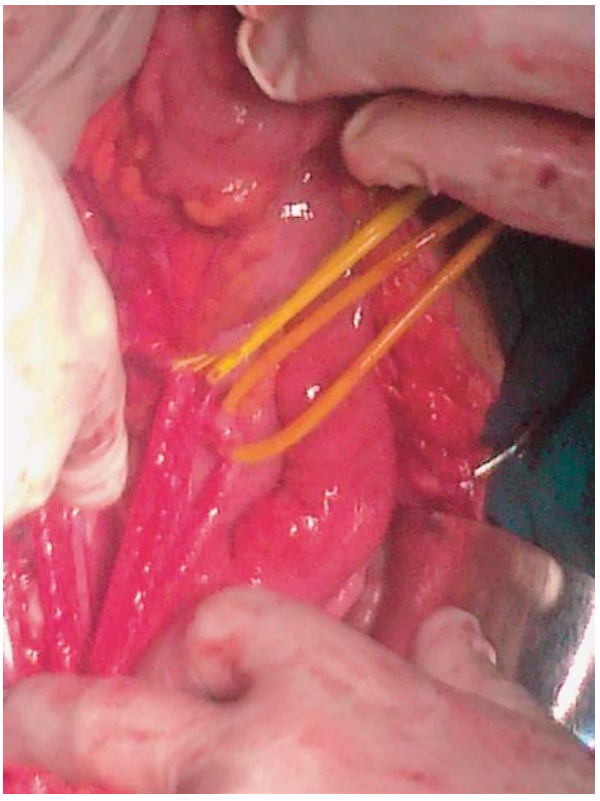

Fig. 1. Intraoperative finding of ureteral triplication.

Blaustein's Pathology of the Female Genital Tract, $6^{\text {th }}$ edition from 2011, tumor is classified as endocervical adenocarcinoma, usual type; according to TNM classification, $7^{\text {th }}$ edition from 2009 , tumor is classified as T1bNXMX).

Radical surgery according to our protocol was indicated. No macroscopically visible pathologic substrate was found. While performing left obturator fossa lymphadenectomy, ureteral triplication was found all the way to the bladder entrance (Fig. 1). Ureter on the right side was without abnormalities.

On postoperative day 7, the patient underwent intravenous urography, which showed duplicated collecting system of the left kidney and left ureter duplication in the proximal part (Fig. 2).

\section{Discussion}

The first known description of ureteral triplication was the one by Wrany in $1870^{1}$. Campbell found only 3 cases in over 47000 autopsies ${ }^{2}$. Ureteral triplications usually are asymptomatic and are incidental finding during surgery for non-related reasons. In some cases, they can be related to other malformations, as well as symptoms of pyelonephritis ${ }^{9}$. These patients have a higher incidence of recurrent urinary tract infections, renal colic and secondary incontinence due to obstruc-

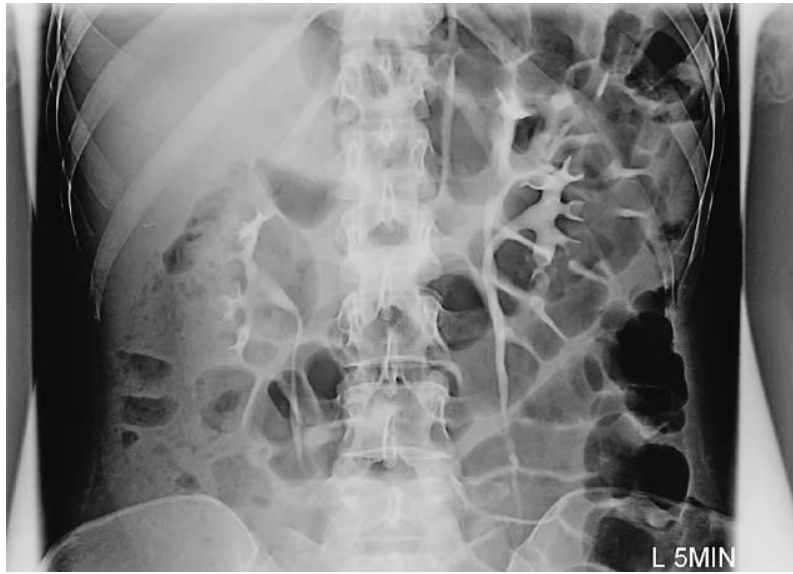

Fig. 2. Intravenous urography.

tion and reflux ${ }^{9}$. Operative procedure is considered in cases where symptoms decrease the patient's quality of life. The type of surgical treatment depends on symptom manifestation. The risk of renal failure is usually a deciding factor, which can be found in conditions such as vesicoureteral reflux, obstruction, ureteral ectopy and recurrent infections. Simultaneous treatment of upper and lower urinary tract can be performed ${ }^{10}$.

Our patient presented with type 2 ureter triplication, clinically asymptomatic. This type occurs in about one fifth of all ureter triplications ${ }^{3,9}$.

Ureteral triplication occurs when three separate ureteric buds develop from a single wolffian duct, or if two ureteric buds develop from mesonephritic duct, and then one divides further into two parts. If some of those developing ureters do not merge with metanephros, a 'blind-ending' ureter occurs. Other anomalies that usually occur with ureteral triplication are ureteral duplication on the opposite side, ureteric orifice ectopy and kidney dysplasia ${ }^{11}$.

In some cases of ureteral triplication, one or more ureters can be ectopic with vaginal insertion ${ }^{5}$. Ureteral quadruplication is extremely rare, and there are only around 10 cases found in the literature ${ }^{12}$. There is also a case report of quintuple ureter found in a 3-year-old child. The child was born in a place 60 kilometers from Chernobyl, 24 years after the nuclear incident ${ }^{13}$.

Urogenital anomalies account for 30\%-40\% of all anomalies in children. Most of them show no clinical symptoms, but if they do, urinary infection is the most common symptom ${ }^{11}$. If ureteral duplication or triplication is suspected detailed imaging is required. 


\section{References}

1. Li J, Hu T, Wan M, Chen S, et al. Ureteral triplication: the first report in China. J Pediatr Sung. 2004;39:E38-9. http://dx.doi. org/10.1016/j.jpedsurg.2003.09.039.

2. Campbell M. Embryology and anomalies of the urogenital tract. In: Clinical Pediatric Urology, $1^{\text {st }}$ edn. Philadelphia: WB Saunders, 1951;159-65.

3. Smith I. Triplicate ureter. Br J Surg. 1946;34:182-5. http:// dx.doi.org/10.1002/bjs.18003413409.

4. Villanueva Peña A, De Diego Rodríguez E. [Ureteral triplication, an unusual isolated presentation]. Actas Urol Esp. 2004; 28(10):766-70. (in Spanish) http://dx.doi.org/10.1016/s02104806(04)73179-4.

5. Engelstein D, Livne PM, Cohen M, Servadio C. Type II ureteral triplication associated with ectopic ureter. Urology. 1996;48(5): 786-8. http://dx.doi.org/10.1016/S0090-4295(96)00323-8.

6. Singh G, Murray K. Ureteral triplication, occasionally an isolated anomaly. Urol Int. 1996;56(2):117-8. http://dx.doi.org/ $10.1159 / 000282826$.

7. Sánchez-de-Badajoz E, Ramos J, Burgos R. Ureteral triplication with contralateral ureter duplication. Urol Int. 1992;48 (2):217-8. http://dx.doi.org/10.1159/000282336.
8. Golomb J, Ehrlich RM. Bilateral ureteral triplication with crossed ectopic fused kidneys associated with the VACTERL syndrome. J Urol. 1989;141(6):1398-9. http://dx.doi.org/ 10.1016/s0022-5347(17)41321-8.

9. Lee M, Lee Z, Eun D. Intraureteral and intravenous indocyanine green to facilitate robotic partial nephroureterectomy in a patient with complete ureteral triplication. Korean J Urol. 2015; 56(6):473-6. http://dx.doi.org/10.4111/kju.2015.56.6.473.

10. Flechsig H, Fuchs J, Warmann SW, Schaefer JF. Magnetic resonance nephrography for planning of laparoscopic partial nephrectomy in a pediatric case of ureteral triplication. J Pediatr Surg. 2010;45(10):2053-7. http://dx.doi.org/10.1016/j. jpedsurg.2010.05.060.

11. Zivković D, Varga J, Grebeldinger S, Borisev V. [Ureteral triplication - a case report]. Med Pregl. 2005;58(11-12):592-5. (in Serbian) http://dx.doi.org/10.2298/mpns0512592z.

12. Vicentini FC, Denes FT, Srougi M. Ureteral quadruplication associated with ureteral cyst and massive vesicoureteral reflux treated by laparoscopic nephroureterectomy. J Endourol. 2007; 21(7):769-71. http://dx.doi.org/10.1089/end.2006.0249.

13. Jurkiewicz B, Ząbkowski T, Shevchuk D. Ureteral quintuplication with renal atrophy in an infant after the 1986 Chernobyl nuclear disaster. Urology. 2014;83(1):211-3. http://dx.doi.org/ 10.1016/j.urology.2013.07.031.

Sažetak

\section{SLUČAJAN NALAZ TROSTRUKOG URETERA NAĐENOG TIJEKOM OPERACIJE CERVIKALNOG KARCINOMA}

\section{Butorac, I. Djaković, J. Malčić i Lj. Jokanović}

Anomalija trostrukog uretera je iznimno rijetka anomalija gornjeg urotrakta. Također može biti povezana s povećanom incidencijom kongenitalnih anomalija, kao i s predispozicijom za češće mokraćne infekcije, no nije nužno klinički značajna. Kod postojanja simptoma koji smanjuju kvalitetu života svakako treba razmišljati o operativnom zahvatu koji se planira ovisno o vrsti tegoba koje trpi bolesnik. Kirurško liječenje bolesnika s utrostručenjem uretera obično je indicirano ako postoji rizik bubrežnog zatajenja. Ta stanja su najčešće vezikoureteralni refluks, opstrukcija, ureteralna ektopija i ponavljajuće infekcije. Kirurški zahvat može uključiti istodobni tretman gornjih i donjih mokraćnih putova. Prikazuje se slučaj 38-godišnje bolesnice kojoj je tijekom radikalne operacije raka vrata maternice pronađen slučajan nalaz trostrukog lijevog uretera.

Ključne riječi: Trostruki ureter; Karcinom vrata maternice; Kongenitalne anomalije 